\title{
CORPORATE CONTROL IN EUROPE
}

\author{
Marco Becht \\ ECARES, Université Libre de Bruxelles
}

and

Colin Mayer

Said Business School, University of Oxford ${ }^{\text {[ }}$

10 September 2000

This paper was prepared for the Kiel Week Conference "The World's New Financial Landscape: Challenges for Economic Policy", June 19-20, 2000 at the Institut für Weltwirtschaft an der Universität Kiel. It is an abridged version of the introduction to a forthcoming book entitled "The Control of Corporate Europe" which reports the results of an international study of corporate control in Europe undertaken by research members of the European Corporate Governance Network : Jonas Agnblad, Erik Berglöf, Marcello Bianchi, Magda Bianco, Laurence Bloch, Ekkehart Böhmer, Ariane Chapelle, Rafel Crespí-Cladera, Abe de Jong, Luca Enriques, Miguel A. García-Cestona, Marc Goergen, Klaus Gugler, Peter Högfeldt, Rezaul Kabir, Susanne Kalss, Elizabeth Kremp, Teye Marra, Luc Renneboog, Ailsa Röell, Alex Stomper, Helena Svancar, Josef Zechner. This paper draws on the results of the collective research of the Network. We are grateful to our discussant, Erik Berglöf, and to participants at the conference for very helpful comments. 


\begin{abstract}
Data from the EU's Large Holdings Directive (88/627/EEC) allow detailed analyses of the control of European corporations to be undertaken for the first time. This paper reports results from an international study of these data by members of the European Corporate Governance Network. It records high levels of concentration of control of corporations in many European countries with single blockholders frequently controlling more than $50 \%$ of corporate votes. In contrast, a majority of U.K. listed companies have no blockholder owning more than $10 \%$ of shares and a majority of U.S. listed companies have no blockholder with more than $6 \%$ of shares. Distributions of voting blocks reveal that control is concentrated in forms in which regulation confers particular advantages: shareblocks are concentrated at levels at which there are significant control benefits. This suggests a relation between regulation and the structure of ownership of companies that goes beyond existing "over-", "under-" or "optimal-regulation" theories. The paper discusses an alternative view that ownership is largely irrelevant in the face of dominant management control. It also considers a contending thesis that the technology driven project realisation periods are relevant to the period for which corporate control needs to be exerted.
\end{abstract}

JEL Classification : G31; G34

Keywords: corporate governance, ownership, control, regulation 


\section{Existing studies of ownership and control}

The classic study of the ownership and control of corporations is Berle and Means, 1932. On the basis of an analysis of US corporations, they concluded that "the separation of ownership from control has become effective - a large body of security holders has been created who exercise virtually no control over the wealth which they or their predecessors in interest have contributed to the enterprise.....The separation of ownership from control produces a condition where the interests of owner and of ultimate manager may, and often do, diverge, and where many of the checks which formerly operated to limit the use of power disappear." (pages 6 and 7 in 1968 edition).

Berle and Means' analysis stimulated a huge literature on the control problems created by the separation of ownership and control. Their arguments were amplified in "the corporation problem" literature of the 1960s. Manne (1965) argued that the market, not management, controls the "modern corporation" but Grossman and Hart (1980) cast doubt on the effectiveness of the takeover mechanism. Pessimism culminated in Jensen's (1989) prediction of "The Eclipse of the Public Corporation" and a move to private corporations with high levels of debt. Recently the U.S. public corporation, with apparently strong outside directors, shareholder activists and strong legal protection of shareholders, is again the global favourite. But the latest evidence suggests that managers are as powerful as ever. Weak boards with ample formal power, insurmountable takeover barriers and anti-blockholder regulations continue to prevent owners from exerting control.

To date, very little is known about the control of corporations outside the United States. In fact, such has been the influence of Berle and Means that the textbook description of dispersed ownership and separation of ownership and control has been presumed to be universally applicable. But over the last few years, evidence has emerged that has questioned this view.

In the Kiel week conference in 1994, Franks and Mayer (1995) described two types of ownership and control structures - what they termed the "insider and outsider" systems. The outsider system corresponds to the Berle and Means description of the 
US - ownership is dispersed amongst a large number of outside investors. Both the UK and US have outsider systems. In the UK, a majority of equity is held by financial institutions, predominantly pension funds and life assurance companies. In the US, individual shareholders are more widespread. But in neither country do institutions or individuals hold a large fraction of shares in a company. As a consequence, they exert little direct control over corporations and the separation of ownership and control described by Berle and Means is observed.

However, Franks and Mayer also noted a quite different system that existed in Continental Europe. There, few companies are listed on stock markets and those companies that are listed have a remarkably high level of concentration of ownership. Franks and Mayer observed that in more than $80 \%$ of the largest 170 companies listed on stock markets in France and Germany, there is a single shareholder owning more than $25 \%$ of shares. In more than $50 \%$ of companies, there is a single majority shareholder. The corresponding figures for the UK were $16 \%$ of largest 170 listed companies had single shareholders owning more than $25 \%$ of shares and $6 \%$ had single majority shareholders. Concentration of ownership is staggeringly high on the Continent in comparison with either the UK or US.

Franks and Mayer noted that the ownership of Continental European companies is primarily concentrated in the hands of two groups: families and other companies. Cross-shareholdings and complex webs of inter-corporate shareholdings are commonplace in some countries. Companies frequently hold shares in each other in the form of pyramids by which company A holds shares of company B which holds shares of company $\mathrm{C}$ etc. They also observed that bank ownership of corporate equity was generally quite modest, despite the attention that has been devoted to the role of bank shareholdings in cementing bank-firm relations. In some but by no means all Continental European countries, ownership by the state is appreciable. Barca et al (1994) report similar results for Italy.

La Porta et al (1997 and 1999) have recently extended Franks and Mayer's study to many more countries. They have found that the observation on insider systems which Franks and Mayer made about Continental European countries applies widely around 
the world. They conclude that the Berle and Means corporation is much less applicable than previously thought. Instead, the insider system appears to dominate.

Interesting though these studies are, they both have serious methodological problems. Firstly, the coverage of the studies is very limited. The Franks and Mayer analysis refers to the largest 170 firms in France, Germany and the UK. The La Porta et al study is restricted to the largest 20 firms in each of their 27 countries. ${ }^{\text {B }}$ Franks and Mayer have a reasonably large number of large corporations but in a very small number of countries; La Porta et al have a very small number of companies in a large number of countries.

Secondly, the analysis of control in both papers is rudimentary. In fact, though both papers refer to ownership, what they actually measure is voting control. Data on ownership are in general simply not available and all that can be measured is voting rights. More significantly, an analysis of control of corporations is complex. In a subsequent paper on Germany, Franks and Mayer (1995) noted that shareholdings are frequently in the form of pyramids in which the control that the owner at the top of the pyramid exerts can be disproportionate to the cost of their investments as measured by their cash flow rights. In order to identify where control resides, it is necessary to trace it back up through the pyramid to the ultimate shareholders at the top of the pyramid. La Porta et al attempt to do this but their data cannot capture the full complexity of control arrangements that exist in corporate Europe, as we describe below.

Over the last few years, the possibility of undertaking a much more precise analysis of the control of European corporations has emerged. This has arisen as a consequence of vastly improved disclosure standards in Europe. To facilitate the creation of a truly European equity market, the European Union has adopted the Large Holdings Directive (88/627/EEC). This Directive has created the unique opportunity to study corporate control. Access to these data has been improved by cross-listings and integration of capital markets. Companies with a foreign listing in the United States have to file a Form 20-F that includes a special section on the "Control of the Registrant". Voting blocks of $10 \%$ or larger that have been reported to the companies as a result of the European directive must be disclosed. In future, it will also be 
possible to perform this type of analysis in Eastern Europe since before they can join, the accession countries of the European Union will have to transpose the European Union's Directives. As a result, better information on voting power concentration will become available for these countries as well. Internationally, the OECD Principles of Corporate Governance and related efforts by IOSCO are likely to make disclosure more effective and to provide further research opportunities.

Until a few years ago, international comparisons of financial systems focused on the financing of firms and, in particular, the role of banks in funding companies. Distinctions were drawn between supposedly bank oriented financial systems, such as Germany and Japan, and the market oriented systems of the UK and US. But closer analysis revealed the fragility of these distinctions. Mayer (1988), Edwards and Fischer (1994) and Corbett and Jenkinson (1996) noted that the amount of lending coming from German banks has been modest over a long period of time. Edwards and Fischer (1994) argued that there is little support for the conventional wisdom that German banks are actively involved in monitoring and controlling corporations.

In the case of East Asia, in particular Japan, research focused on the relative performance of keiretsu and non-keiretsu companies (Aoki, 1990; Prowse, 1992; Kaplan, 1994). Initially it appeared that the closer bank-firm relations in keiretsu groups are reflected in fewer credit constraints and the provision of more financing during periods when companies are in financial difficulty (Hoshi, Kashyap and Scharfstein, 1991). However, even this view has been questioned over the last few years. Kang and Stulz (1997) reported that bank dependent firms suffered significantly larger wealth losses and invested less than other firms during 1990 to 1993 when the Japanese stock market dropped appreciably. Weinstein and Yafeh (1998) recorded that close bank-firm ties increased the availability of capital to Japanese firms but did not lead to higher profitability or growth because of banks' market power.

The distinction between bank and market oriented financial systems is therefore fragile. In contrast, the differences in ownership and control of corporations noted above are pronounced. This raises two questions. Firstly what are their causes and, secondly, what are their consequences. We examine existing debates on these two issues in section 2 of the introduction. In section 3 we summarise the results of the 
European Corporate Governance Network study and in section 4 we conclude the paper.

\section{The causes and consequences of ownership concentrations}

Over the last few years much attention has been given to the influence of regulation and legal form on corporate ownership and control. Black (1990) and Roe (1994) pioneered the "over-regulation" thesis that has been a dominant force in the debate. Roe (1994) documents that regulation prevents potentially important investors from holding blocks. Black (1990) argues that regulation makes it costly to hold blocks and causes shareholder passivity in the United States.

If the separation of ownership and control is induced by regulation and not efficient, why was the regulation introduced and why is it not repealed? Roe argues that the rise of the Berle and Means corporation in the United States was not simply a response to the forces of economic efficiency but a reflection of populist politics. Concerns about concentration of control in particular in the hands of such banks as J.P. Morgan led to a backlash in the imposition of regulation restricting the involvement of banks in corporate activities. Dispersed ownership therefore resulted from the introduction of regulatory impediments to concentrations in ownership prompted by a populist political agenda. Bebchuk and Roe (1999) argue that inefficient regulation can persist as a result of "path-dependence".

The over-regulation argument views the difference between the US and other countries as reflecting impediments to the free choice of corporate structure in the US. However, over the last few years an exactly contrary view has been presented. Far from US corporations being impeded by regulation from choosing appropriate structures, "under-regulation" and, in particular, weak investor protection undermine the financing of firms in most countries of the world. According to La Porta et al (1997), concentrations of ownership and complex control vehicles are a response to inadequate protection of investors. Faced with a risk of exploitation by self-interested managers, investors require powerful mechanisms for exercising control and they do so through holding large ownership stakes in companies and exerting voting power that is disproportionate to the amount that they invest in firms. This argument has 
been formalised by Bebchuk (1999), who presents a rent-seeking theory of the evolutions of ownership and control and voting power leverage respectively. If blockholder control is induced by under-regulation and not efficient, why has no regulation been introduced? La Porta et. al. (2000) invoke similar arguments to those of Roe (1994) and Bebchuk and Roe (1999): rent seeking blockholders are powerful and have prevented stock exchanges and regulators from curbing their power.t

Easterbrook and Fischel (1991) adopt a third position. They argue that the corporate structures we observe have an economic purpose. The Berle Means corporation and the closely held corporation are efficient, but in different contexts. If they were not, they would not have grown and survived. Easterbrook (1997) argues that the structure and needs of the financial system and the forces of the market create the necessary regulation, not the other way round.

Roe views the US corporation as being weighed down by regulatory restrictions imposed by an earlier political agenda; La Porta et al argue that strong investor protection in common law countries and under-regulation elsewhere has allowed external financing to occur on a larger scale under common law. Easterbrook (1997) argues that the size of a country's stockmarket, as determined, for example, by its pension system, determines regulation. For Roe, the regulatory barriers to, for example, bank participation in corporate ownership should be broken down. For La Porta et al, stronger investor protection is required in most countries of the world. For Easterbrook and Fischel, regulation adapts to the needs of the market.

In this paper, we show that regulation visibly affects the relationship between ownership and control. We consider how the control of dominant investors changes as outside ownership is brought in. Dual class shares, non-voting shares and pyramids allow dominant investors to exert disproportionate degrees of voting power as outside ownership comes in. This is termed "a private control bias". Rules preventing or discouraging shareholders from exercising voting rights, in particular in takeovers or board elections, lead to a dispersion of voting power. This can either create a market or a management control bias. In the absence of anti-takeover devices dispersed voting power can be exercised through a hostile bid; Manne's (1965) market for corporate control. If the bidder holds a minority stake of sufficient size or has other 
incentives to launch a bid, minority investors can free ride on the control exerted by others and thereby derive control disproportionate to their investment. However, rules that discourage voting blocks can also lead to a "management bias". In most countries a variety of formal and informal devices shielding management from external control exist (poison pills, voting caps, weak and captured boards). Protecting minorities by curbing the voting power of the blockholder can severely tilt the balance of cash-flow rights and power in favour of management.

Figure 1 illustrates. It shows that rules protecting dominant investors push the line linking ownership to control upwards to the left. Control therefore declines less than proportionately with reduction in ownership. On the other hand, rules preventing or discouraging shareholders from exercising voting rights push the ownership: control line down to the right. Control then declines more than proportionately with ownership.

There is a similar divergence of view about the consequences of ownership concentration. The most popular view of corporate governance is the agency one. Managers run firms according to their own interests and agenda when the company is widely held. As far as possible, incentives are used to align the interests of managers and shareholders but active monitoring and control of companies is also required. But as noted by Berle and Means, in the presence of dispersed ownership, investors have little incentive to engage actively in this and instead prefer to "free ride" on the monitoring performed by others. Some ownership concentration is therefore required to ameliorate managerial agency problems (Berle 1958).

But while concentrations of ownership may reduce agency problems, they create a second conflict. The interests of holders of large blocks of shares may diverge from those of minority investors. Large shareholders are in a position to engage in activities that benefit them at the expense of minority investors. In Jensen and Meckling (1976) the owner-manager can freely choose the level of private benefit consumption because he/she retains all control rights while selling only cash-flow rights. The most obvious example of such "private benefits" is shifting assets and corporate value through transfer pricing between companies in which large shareholders have an interest. In some countries there are explicit restrictions on these 
activities, requiring for example, that parent and subsidiary act on an arms-length basis and use market testing to price transactions. In other countries, there are few restrictions.

While the "over-regulation" literature sees weak owners confronted with strong managers in countries with dispersed ownership, the rent-seeking literature argues that strong owners in countries with concentrated ownership and/or control exploit weak minorities. In particular, La Porta et al have argued that the latter is the more serious problem confronting most countries and the emergence of ownership concentrations in the face of weak investor protection is a deficiency not an advantage of these systems.

Carlin and Mayer (2000a and b) and Mayer (2000) argue that there is no one dominant system. Different types of ownership and control are suited to different types of activities. They argue that concentrated ownership benefits activities that require long-term, committed investors. Dispersed ownership benefits short-term investments that require greater flexibility and less commitment. In particular, Mayer (2000) argues that there is a need to match periods for which control can be expected to be retained (what is termed the "influence period") with the "realisation period" of projects (the time taken for projects to come to fruition). Too short an influence relative to a realisation period leads to rejection of long-term investments. Too long an influence relative to realisation period leads to inefficient retention of control. Dominant owners are able to retain control over long periods whereas managers facing markets in corporate control with dispersed ownership are subject to short influence periods. The latter therefore promote efficient transfers in control for investments with short realisation periods whereas the former encourage investments in activities with long realisation periods.

\section{Results}

Traditionally, European corporations and their shareholders value privacy. In Austria, Belgium, Denmark, France, Germany, Luxembourg, the Netherlands, Portugal and Spain most listed companies issue bearer shares. By definition, ownership and voting power are hard to trace. However, this can also be difficult in countries with registered shares (Finland, Greece, Ireland, Italy, Sweden and the United Kingdom). 
Company law and securities regulations do not always force companies to provide access to share registers; alternatively, shares might be held in nominee accounts ("street names"). Even when the names of the beneficial owners are known, the share register provides no information on voting pacts and other arrangements that tie individual stakes into blocks of votes cast by the same person or entity.

The comparative analysis in this paper relies on a new disclosure standard that partially overcomes these problems. It applies throughout the European Union and provides for the disclosure of $10 \%+($ often $5 \%+$ ) voting blocks.

\subsection{Average size of voting blocks}

Table 1 reports the proportion of votes controlled by the largest voting block in eight countries. In $50 \%$ of non-financial listed companies in Austria, Belgium, Germany and Italy, a single blockholder (an individual investor or group of investors) controls more than $50 \%$ of voting rights. In $50 \%$ of Dutch, Spanish and Swedish companies, more than $43.5 \%, 34.5 \%$ and $34.9 \%$ respectively of votes are controlled by a single blockholder. In contrast, the median blockholder in the UK controls only $9.9 \%$ of votes and in the United States the median size of blockholding of companies quoted on both Nasdaq and NYSE is just above the disclosure level of 5\% (8.6\% and 5.4\%).

The picture looks very different when one goes down to the second and third largest blocks (table 1). The median size of the second largest voting block is $2.5 \%$ in Austria, $10.2 \%$ in Belgium, 5.9\% in France, $7.6 \%$ in Italy and $8.7 \%$ in Sweden. In Germany it is below the disclosure level. The median size of the third largest voting block is $4.7 \%$ in Belgium, 3.4\% in France, 3.0\% in Italy and 4.8\% in Sweden. In both Austria and Germany it is below the disclosure level. The size of voting blocks therefore decreases rapidly beyond the largest shareholder. Voting power is concentrated on the Continent not only because of the existence of large blockholders but also because of the absence of other voting blocks.

In the UK, the median size of the second largest block is $7.3 \%$, and of the third largest block is $5.2 \%$. The size of the largest block is therefore appreciably smaller in the UK than on the Continent but the size of blocks does not decline very rapidly thereafter. Indeed, the third largest block and beyond is larger in the UK than any other country 
in this study. Even beyond the tenth largest block holding, the mean voting block in the UK is greater than $3 \%$, whereas it is below disclosure levels in virtually all the continental European countries in this study. On the Continent, the largest block holder exerts dominant voting control in relation to other block holders. In the UK, no individual block holder in general exerts dominant control; instead it can only come from coalitions of investors. The situation is the same in the United States but the potential coalition to exert effective control must be even larger than in the UK.

Voting power is much more concentrated on the Continent than in the UK or the US. Coalitions between shareholders are required in the UK and US to exercise control. This points to a private control bias on the Continent and a management or market control bias in the UK and US. The next section will provide support for this from an analysis of distributions of voting control in different countries.

\subsection{Distributions of voting control}

Figures 2 to 11 show the cumulative distributions of largest voting blocks (from smallest to largest) in listed companies in seven European countries and for NYSE and NASDAQ companies in the US. The figures report the fraction of companies in a country with largest blocks less than the values reported on the vertical axis. A cumulative distribution close to the $45^{\circ}$ line reflects a uniform density of firms by voting blocks. A distribution above the $45^{\circ}$ line reflects a preponderance of large voting block companies and a distribution below the $45^{\circ}$ line indicates a large amount of dispersed voting control.

In Germany, the cumulative distribution is above the $45^{\circ}$ line; in Austria, Belgium, and Italy, the distributions are close to the $45^{\circ}$ line. In the Netherlands and Spain they are below the $45^{\circ}$ line. But the real contrast is between the UK and US on the one hand and Continental Europe on the other. The distributions for firms in the UK and US (both NYSE and NASDAQ firms) are very similar. In the US a majority of shareholdings are below the disclosure level of 5\% and there are very few majority voting block companies in either country. The UK and US therefore display pronounced market/ management control bias; the Netherlands and Spain weak 
management control bias; the Austrian, Belgian and Italian distributions are quite neutral and Germany displays a private control bias.

Still more interesting are the concentrations of firms on the distributions. In Austria and Germany there is clear bunching of firms around 25\%,50\% and 75\% voting blocks. These correspond to significant voting levels in both countries (blocking minority, majority and super-majority voting). In Belgium and Italy there are concentrations just in excess of 50\% voting blocks. In the UK, there are few blocks in excess of $30 \%$. This corresponds to the level at which mandatory bids have to be made for all the shares of a target company. Takeover rules have therefore discouraged the accumulation of share blocks in excess of $30 \%$ in the UK. In the US shareholdings in excess of $10 \%$ and $20 \%$ may have undesirable regulatory control implications (in terms of disposal of shares and liabilities for federal law violations; see Black 1990). This is consistent with the concentrations of ownership below $10 \%$ and $20 \%$ and the small number of shareholdings in excess of $20 \%$ of companies on the NYSE.

The plots suggest that regulation has a significant influence on control patterns in different countries. Shareholder protection, through measures that curb voting power or make it hazardous to exercise, and anti-takeover rules have given rise to a management control bias in the UK and US. Weak minority protection and leverage control devices have created a private control bias in Germany and, still more significantly, voting blocks are concentrated around critical levels determined by regulatory rules in different countries.

\subsection{Ownership of voting blocks}

Not only does the scale of corporate control differ appreciably across countries but so too do the parties who exert it. Table 2 shows the number of blocks and the mean, median, minimum and maximum size of blocks held by different classes of investors in Austria, Germany, Italy, Spain, the Netherlands and the United Kingdom. Figures 11 and 12 show the number of reported blocks owned by different classes of investors in UK, German and Austrian companies. 
The UK: As is well known, financial institutions, pension funds and life insurance companies are the dominant class of shareholders in the UK. Figure 12 records that they hold $62 \%$ of the recorded blocks in the UK. While financial institutions dominate in terms of numbers of blocks, table 2 records that the size of blocks held is relatively small. The median size of blocks held by insurance companies is $4.0 \%$ and by investment and pension funds is $7.0 \%$.

Austria and Germany: Figure 13 shows that in Germany and Austria, families and individuals and other companies have the largest blockholdings. In Germany, individuals and families hold $32 \%$ of blocks, other companies $28 \%$, trusts and holding companies $21 \%$, financial institutions $17 \%$ and government 3\%. In Austria, individuals and families hold $45 \%$ of blocks, companies $36 \%$, financial institutions $11 \%$ and government $9 \%$. The median size of block held by families is $26.9 \%$ in Germany and $26.0 \%$ in Austria. The median size of blocks held by companies is much larger than that of families in Germany (61.6\%) and somewhat larger in Austria (39.4\% for domestic firms).

Italy: Table 2 records a dominant role for families and domestic firms in Italy. Pyramidal holdings are widespread and are primarily associated with holdings by families, coalitions of corporate shareholders and the state. Financial institutions, including banks, have only played a limited role in the ownership of Italian companies.

The Netherlands: In the Netherlands, there are a substantial number of large blocks held by administration offices that are often controlled by the boards of the companies they control.

Belgium: Foreign ownership is an important feature of Belgian corporate control, in particular from France and Luxembourg. Control is sometimes exerted via pyramid structures and, as in other Continental European countries, a range of anti-takeover devices are employed. The case of Solvac illustrates these (see figure 14). Solvac is a listed company but has registered shares that can only be held by private investors. Solvac S.A. has entered into an agreement with Sofina S.A., Deutsche Bank AG and 
Générale de Banque S.A. to ward off any hostile takeover bids for Solvay S.A. Sofina S.A.is controlled by the Boel, Solvay and Janssen families.

Spain: In Spain, families and firms are again the largest holders of share blocks. The average size of the blocks is similar to that of Italian companies (a median of $16.0 \%$ for family holdings and $24.1 \%$ for domestic firms). The largest holdings have traditionally been associated with the state.

In sum, financial institutions are therefore the largest holders of voting blocks in the UK but their blocks are small on average. In contrast, in most Continental European companies there are substantial voting blocks in the hands of families and companies and a variety of mechanisms intensifying this through the separation of cash flow and voting rights.

However, there is another feature of corporate control in many European countries and that is the ability of management to entrench themselves. In some companies, there are no identifiable owners or owners are disenfranchised through intermediary institutions or lock-in devices. In Austria there are a significant number of companies with no identified owner. For example, the holder of the largest block of more than $40 \%$ of Bank Austria is an ownerless association, Anteilsverwaltung Zentralsparkasse (AVZ). In the Netherlands, the largest blocks of shares are held by "administrative offices". These issue depository shares that give certificate holders the right to attend and speak at shareholders' meetings and to call for extraordinary meetings. But they have no votes; voting rights attached to shares can only be exercised by administrative offices. Often the boards appoint themselves (the so-called "structural regime" that is compulsory for companies with certain characteristics). In Spain and France, voting right restrictions provide formidable protection from shareholder influence and control contests.

An alternative protection device recorded in the Netherlands is to issue preferred shares to friendly investors. These shareholders have the right to make a binding nomination for the appointment of management. "Potential capital" is a further device for preventing transfers of control. They are like poison pills except that issued 
capital goes to friendly investors, for example foundations, in the event of a hostile bid.

Unilever illustrates the operation of these protection devices (see figure 15). Unilever comprises Unilever N.V. - the Dutch part - and Unilever PLC - the UK part. They trade as a single entity. This is achieved through two holding companies N.V. Elma and United Holdings Limited which are held in turn by the Unilever companies and have cross-shareholdings in each other. They in turn hold special shares and deferred stock in Unilever NV and PLC respectively. The significance of these special shares and deferred stock is that only they can nominate persons for elections as members of the Boards of Directors of NV and PLC. In other words, elections to the board of Unilever are by two companies fully owned by Unilever. This is said to be required to "ensure unity of management of the Unilever Group" (Unilever's 20F declaration page 33).

There are far fewer takeover defences available to companies in the UK, but table 2 reports that there are a large number of share blocks held by both executive and nonexecutive directors. In the presence of highly dispersed shareholdings these share blocks may provide management with a significant degree of protection.

There is therefore an alternative to the above conclusions of private control bias on the Continent and management control bias in the UK and US. There is a high degree of management entrenchment in all countries, either through lock-in vehicles on the Continent or through anti-takeover mechanisms in the UK and US. Market control or control by a blockholder who has the best interest of all shareholders in mind are rare.

\subsection{Changing patterns of control}

This paper provides a snapshot of the voting control of European companies at the end of the $20^{\text {th }}$ century. But there is evidence that these patterns are changing. The Agnelli group, for example, has disposed of companies operating in chemicals and cement. Banks are playing a larger role, particularly in companies in financial distress. Takeover legislation requiring mandatory bids when shareholdings reach $30 \%$ is encouraging concentrations of shareownership around this level, as has already been documented for the UK. In Spain, the significance of the state has declined with 
privatizations. Some state control has been maintained through golden shares but these have not been widely applied. In Sweden, cross-shareholdings have largely disappeared. Dual class shares have been eliminated in many firms. There has been more intervention by minority shareholders in, for example, blocking the merger between Volvo and Renault.

With the dismantling of mechanisms for separating cash flow from voting rights comes a move away from private control biases and neutral control. It is unclear how far these processes will go. It is even more unclear whether they will give rise to market control with freely operating markets in corporate control or simply tilt continental Europe to a management control bias with US style managerial entrenchment through anti-takeover devices. The evidence of a free market in corporate control emerging in Continental Europe is limited to date. There is much antipathy towards markets in corporate control both on social grounds and for the short-termist reasons discussed above in relation to "influence" and investment "realization" periods. If control leverage devices are extinguished and voting control as well as cash flow rights become more widely dispersed, we may well see the emergence of more managerial lock-in mechanisms to take their place. It may, for example, be no coincidence that voting caps are reported to be on the rise in France.

\section{Conclusion}

Section 2 described three conflicting views of the influence of regulation on ownership and control of corporations. According to Roe (1994), dispersed ownership and control in the US result from a populist agenda of imposing regulatory impediments on concentration of control in the hands of a small number of investors. According to La Porta et al (1999), the dominance of large shareholder blocks in most countries in the world is a reflection of inadequate investor protection. According to Easterbrook and Fischel (1991) regulation reflects the needs of managers and investors. Roe's thesis implies that corporate governance deficiencies result from over-regulation, La Porta et al's implies that improved corporate governance will come from more regulation, while Easterbrook and Fischel's suggests that Europe and the United States have the regulation and corporate governance systems that are best suited to their activities. 
What emerges from this paper is a remarkable contrast with the traditional, AngloAmerican view of the corporation. Concentration of voting control is strikingly higher in Continental European companies than in their UK or US counterparts. Control is concentrated not only because of the presence of large investors or core investor groups, but also because of the absence of significant holdings by others. In contrast, in the UK and US, not only are there few large shareholders but also the second, third and smaller shareholdings are not appreciably smaller than the largest. This gives rise to the possibility of effective control through coalitions but not by individual shareholders. However, since a typical block in the U.K. is twice as large as in the United States (10\% versus 5\%), the potential for coalition control is larger in the U.K. than in the United States.

Still more striking than differences in average sizes of shareblocks is the complete distribution of the largest shareholdings. In most Continental European countries, there is a fairly uniform distribution of the largest voting blocks. In contrast, in the UK and US there is a strong "market/ management bias" towards dispersed control. However, it would be wrong merely to contrast Continental European with AngloAmerican control. There is a marked variation within Europe, ranging from a "private control bias" in Germany to a modest management control bias of the AngloAmerican variety in the Netherlands and Spain. Indeed, the largest Spanish companies already combine complete protection of management from takeovers with a very broad shareholder base, just like many of their US counterparts. Still more interesting is the concentration of voting blocks around certain critical levels blocking minority and super-majority holdings in Austria and Germany and majority control in several other countries. Regulation has affected the entire pattern and distribution of corporate control in all countries. As a general proposition, we believe that control is concentrated in forms in which regulation confers particular advantages: shareblocks are concentrated at levels at which there are significant control benefits.

We suggested in section 2 that this may be important in terms of the relation between the control and activities of firms. In principle, market control efficiently reallocates control to those who derive the greatest benefit from exerting it. However, it also limits the period for which anyone can expect to be able to retain control ("influence 
periods"). Market control therefore efficiently reallocates control of projects with short "realisation periods" but may discourage the implementation of projects with long realisation periods. According to this view, the relevance of corporate control for real activities is a reflection of the relation of influence to realisation periods. Different types of corporate control and therefore regulatory arrangements are suited to different forms of corporate activities: industries whose investments have short realisation periods thrive in systems with market control whereas those with long realisation periods benefit from management control.

One of the troublesome, or puzzling, implications of our analysis is the fragility of market control. Even in countries where voting power and ownership are dispersed, management control is often not contestable. Devices such as poison-pills, antitakeover charter provisions, options for issuing voting stock to friendly parties and voting caps can be used to limit the control that external investors can exert. Voting power dispersion overestimates the importance of external control in countries, such as the UK and US, which may have a management, not a market control bias. The primary distinction is not then between market and private control but between management and private control. Do projects with short realisation periods not find enough financing or is market control rare because such projects are rare?

Even in countries with dominant shareholders, we have observed a variety of mechanisms that management can employ to protect itself from external investor interference. If, as a consequence, corporations are run by managers who are able to shield themselves from external influence by investors then control by owners will be largely irrelevant. The Berle and Means view of strong managers/ weak owners may therefore be applicable even in the presence of dominant blockholders and the formal distinction between patterns of corporate control may be of little relevance in the face of a class of largely unaccountable management. Whether this alternative description is correct is yet to be established but regardless of whether it is, this paper serves as a reminder of the multifarious nature of capitalism within let alone outside Europe. 


\section{References}

Aoki, M. 1990. Toward an Economic Model of the Japanese Firm. Journal of Economic Literature $28(1): 1-27$.

Barca, F, and M Becht. 2000. The Control of Corporate Europe.

Barca, F, M Bianchi, F Brioschi, L Buzzacchi, P Casavola, L Filippa, and M Paganini. 1994. I Modelli di Controllo e La Concentrazione Proprietaria Messi a Confronto Empiricamente. III vols. Vol. II, Assetti, Proprietà e Controllo Nelle Imprese Italiane Medio-Grandi. Bologna: il Mulino.

Bebchuk, L. 1999. A Rent-Protection Theory of Corporate Ownership and Control. Cambridge, Mass: NBER Working Paper 7203.

Bebchuk, L, and M Roe. 1999. A Theory of Path Dependence in Corporate Ownership and Governance. Stanford Law Review 52 (1):127-170.

Becht, M, and E Boehmer. 2000. Ownership and Voting Power in Germany. In The Control of Corporate Europe, edited by F. Barca and M. Becht.

Becht, M, A Chapelle, and L Renneboog. 2000. Shareholding Cascades : The Separation of Ownership and Control. In The Control of Corporate Europe, edited by F. Barca and M. Becht.

Berle, A A. 1958. "Control" in Corporate Law. Columbia Law Review 58:1212-1225.

Berle, A A, and G C Means. 1932. The Modern Corporation and Private Property. 1991 Transaction Publishers, New Brunswick and London (U.K.) ed. New York: The MacMillan Company.

Bianchi, M, M Bianco, and L Enriques. 2000. Pyramidal Groups and the Separation Between Ownership and Control in Italy. In The Control of Corporate Europe, edited by F. Barca and M. Becht.

Black, B S. 1990. Shareholder Passivity Reexamined. Michigan Law Review 89:520.

Carlin, W, and C Mayer. 2000a, Finance, Investment and Growth, mimeo, University of Oxford

Carlin, W. and C.Mayer. 2000b. How Do Financial Systems Affect Economic Performance. In, Corporate Governance: Theoretical and Empirical Perspectives, edited by X. Vives. Cambridge: Cambridge University Press, 2000.

Corbett, J, and T Jenkinson. 1996. The Financing of Industry, 1970-1989: An International Comparison. Journal of the Japanese and International Economies 10 (1):71-96.

Crespi-Cladera, R, and M A Garcia-Cestona. 2000. Ownership and Control of Spanish Listed Firms. In The Control of Corporate Europe, edited by F. Barca and M. Becht.

De Jong, A, R Kabir, T Marra, and A Roell. 2000. Ownership and Control in the Netherlands. In The Control of Corporate Europe, edited by F. Barca and M. Becht. 
Easterbrook, F H. 1997. International Corporate Differences: Market or Law? Journal of Applied Corporate Finance 9 (4):23-29.

Easterbrook, F H., and D R. Fischel. 1991. The Economic Structure of Corporate Law. Cambridge, Mass: Harvard University Press.

Edwards, J, and K Fischer. 1994. Banks, Finance and Investment in Germany. Cambridge; New York and Melbourne: Cambridge University Press.

Franks, J, and C Mayer. 1995. Ownership and Control. In Trends in Business Organization: Do Participation and Cooperation Increase Competitiveness? edited by H. Siebert. Tubingen: Mohr (Siebeck).

Grossman, S, and O Hart. 1980. Takeover Bids, the Free-Rider Problem and the Theory of the Corporation. Bell Journal of Economics 11 (1):42-64.

Gugler, K, S Kalss, A Stomper, and J Zechner. 2000. The Separation of Ownership and Control : An Austrian Perspective. In The Control of Corporate Europe, edited by F. Barca and M. Becht.

Hoshi, T, A Kashyap, and D Scharfstein. 1991. Corporate Structure, Liquidity, and Investment: Evidence from Japanese Industrial Groups. Quarterly Journal of Economics 106 (1):33-60.

Jensen, M C. 1989. The Eclipse of the Public Corporation. Harvard Business Review 67:61-74.

Jensen, M C., and W H. Meckling. 1976. Theory of the Firm: Managerial Behavior, Agency Costs and Ownership Structure. Journal of Financial Economics 3 (4):305-60.

Kang, J-K and R. Stulz, 1997. Is Bank-Centred Corporate Governance Worth It? A Cross-Sectional Analysis of the Performance of Japanese Firms During the Asset Price Deflation, mimeo.

Kaplan, S N., and B. A. Minton. 1994. Appointments of Outsiders to Japanese Boards: Determinants and Implications for Managers. Journal of Financial Economics 36 (2):225-58.

La Porta, R, F Lopez de Silanes, and A Shleifer. 1999. Corporate Ownership around the World. Journal of Finance 54 (2):471-517.

La Porta, R, F Lopez-de-Silanes, A Shleifer, and R W Vishny. 1997. Legal Determinants of External Finance. Journal of Finance 52:1131-1150.

La Porta, R, F Lopez-de-Silanes, A Shleifer, and R W Vishny. 2000. Investor Protection: Origins, Consequences, and Reform. Journal of Financial Economics forthcoming.

Manne, H. 1965. Mergers and the Market for Corporate Control. Journal of Political Economy:110120.

Mayer, C. 1988. New Issues in Corporate Finance. European Economic Review 32 (5):1167-83.

Mayer, C. 2000. Ownership Matters. Brussels, Inaugural Lecture .

Prowse, S D. 1992. The Structure of Corporate Ownership in Japan. Journal of Finance 47 (3):1121-40. 
Roe, M. 1991. A Political Theory of American Corporate Finance. Columbia Law Review 91 (10).

Roe, M. 1994. Strong Managers, Weak Owners: The Political Roots of American Corporate Finance. Princeton: Princeton University Press.

Weinstein, D. E., and Y. Yafeh. 1998. On the Costs of a Bank-Centered Financial System: Evidence from the Changing Main Bank Relations in Japan. Journal of Finance 53 (2):635-72. 


\section{FIGURE 1}

\section{Private Control Bias ANd Management or Market CONTRol Bias}

Power increases proportionally with ownership under one-share-one-vote, in the absence of pre- and post-bid antitakeover devices and under "neutral" regulation. Rules and devices protecting dominant investors push the line linking ownership to control upwards to the left. Control therefore declines less than proportionately initially with reduction in ownership. On the other hand, strong minority protection pushes the ownership-control line down to the right. Control then declines more than proportionately with ownership. In the absence of anti-takeover devices such as poison pills or voting caps, this will results in a market control bias. More likely, it results in a management control bias.

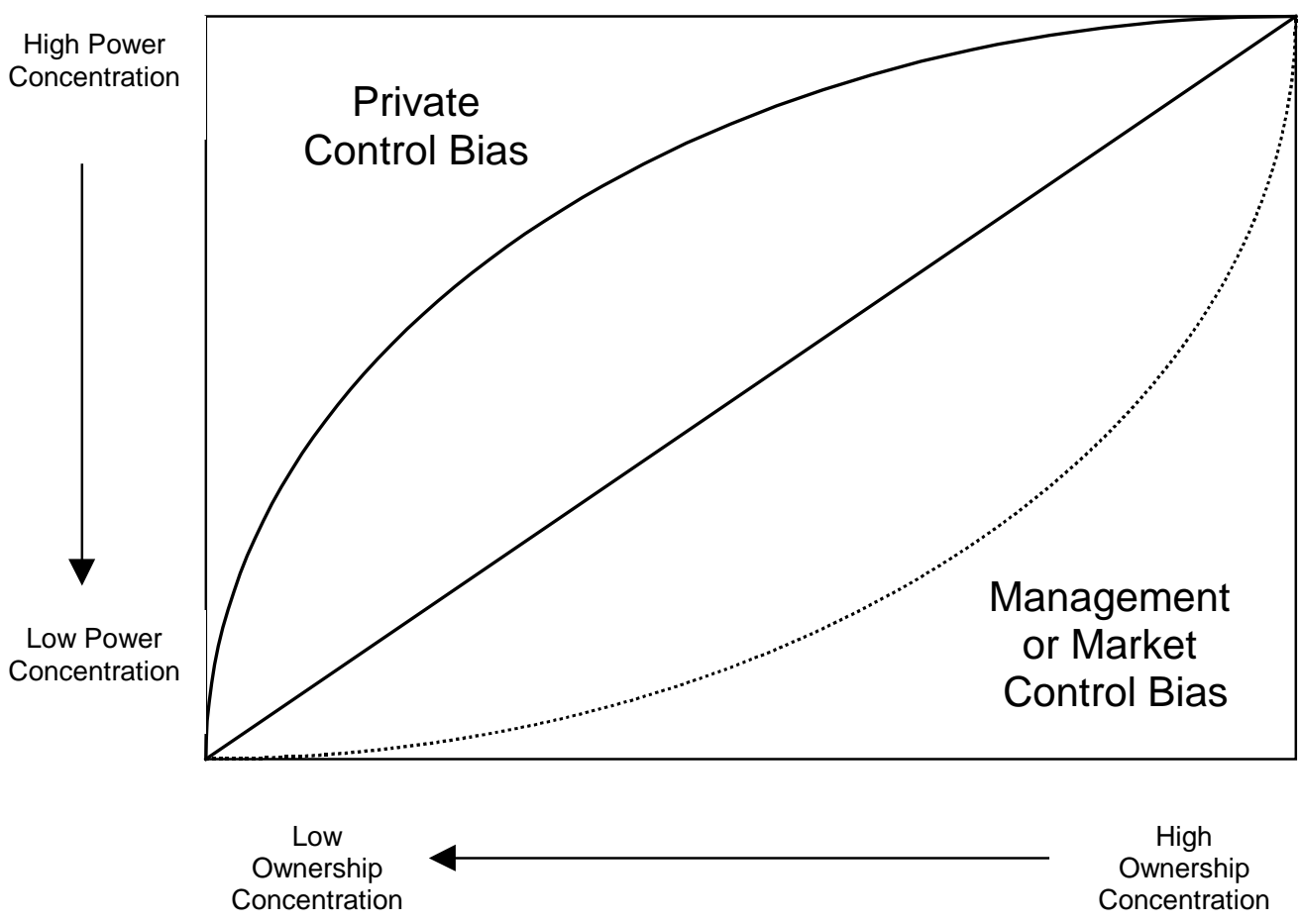




\section{FIGURE 2}

\section{Percentile Plot of Largest Voting Blocks in Austrian Listed Firms}

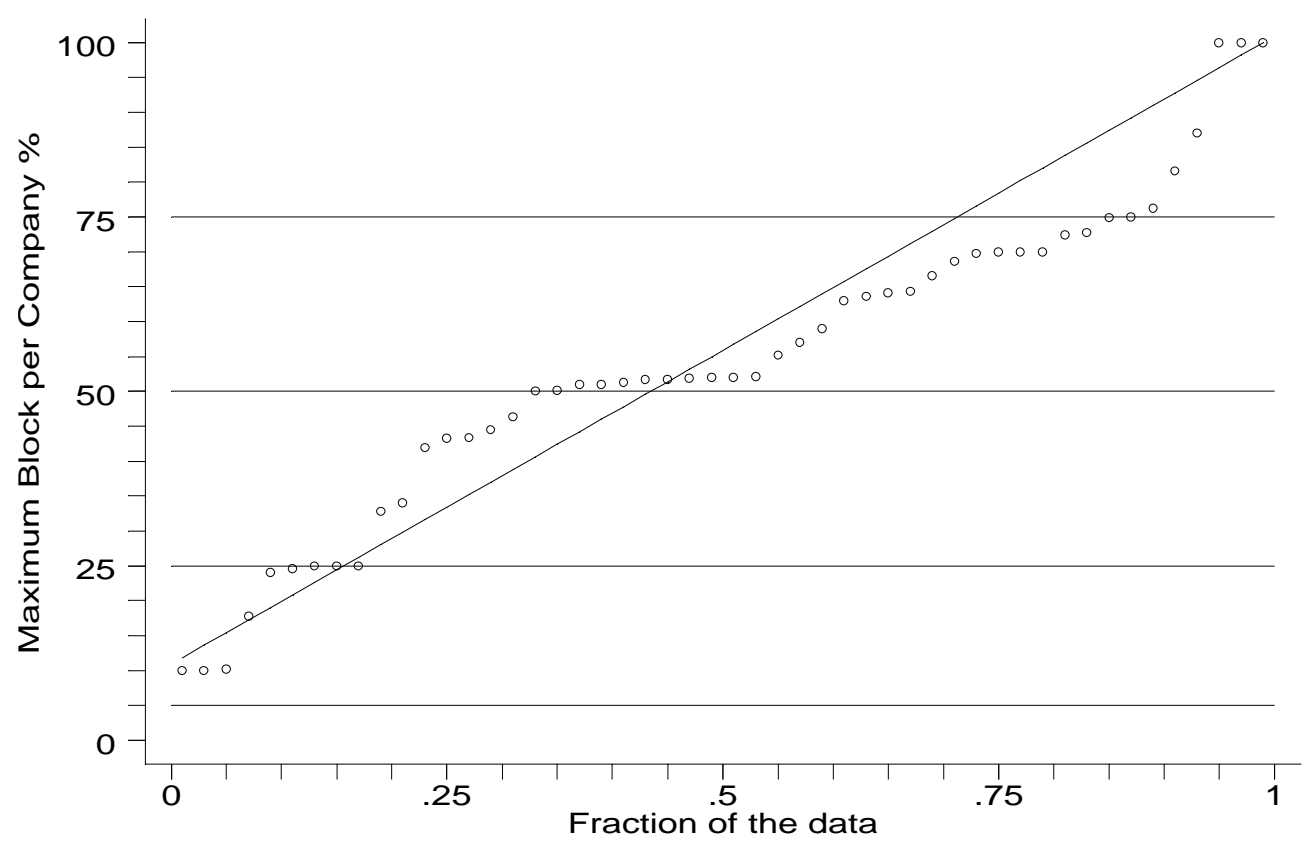

Source : Gugler, Kalss, Stomper and Zechner (2000)

\section{FIGURE 3}

\section{Percentile Plot of Largest Voting Blocks in Belgian Listed Firms}

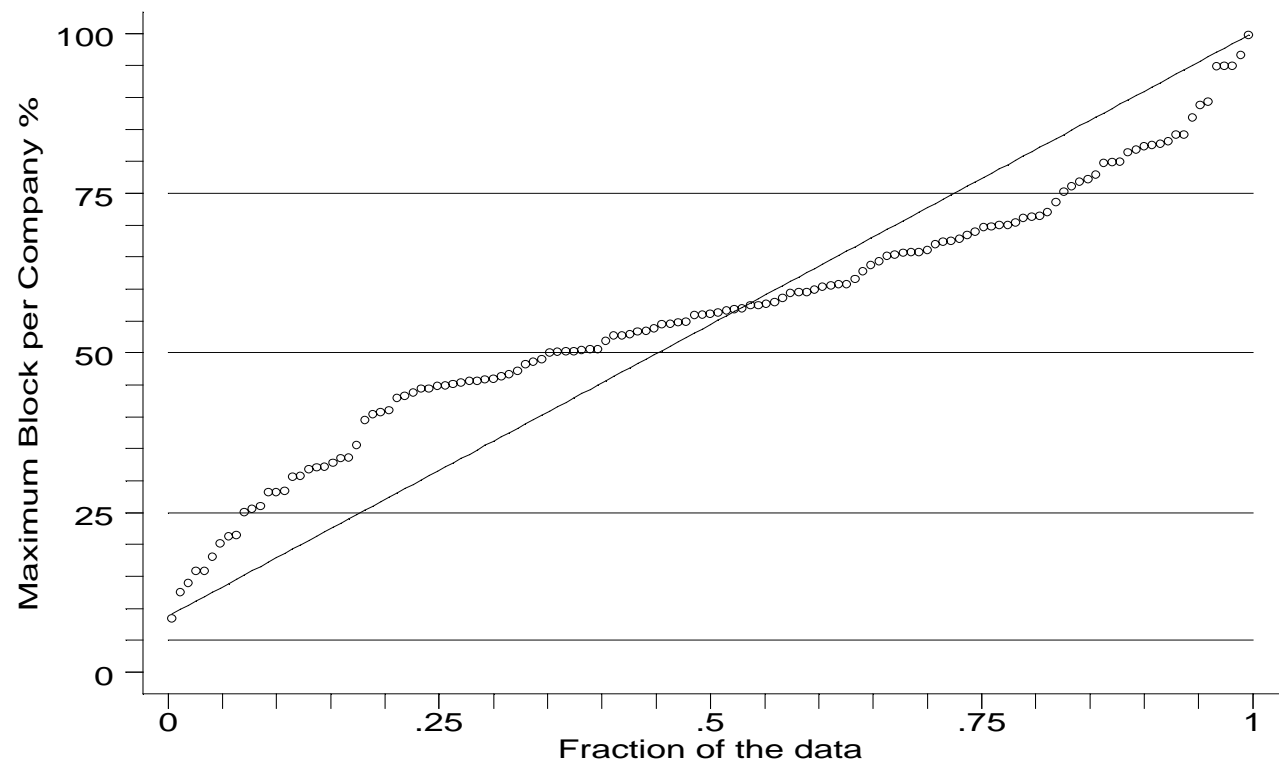

Source : Becht, Chapelle and Renneboog (2000) 


\section{FIGURE 4}

\section{Percentile Plot of LaRgest Voting Blocks in German Listed Firms}

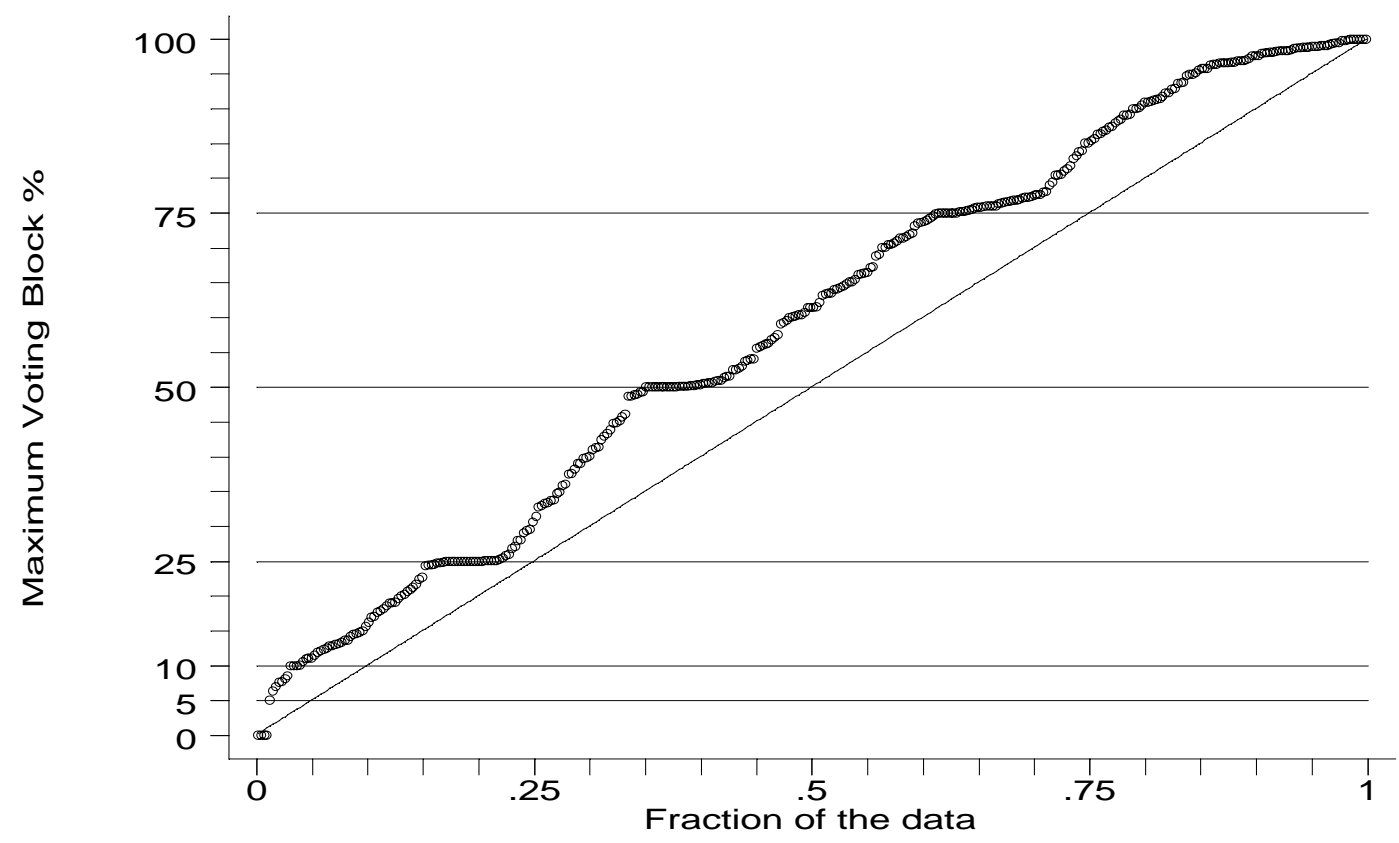

Source : Becht and Böhmer (2000)

\section{FigURE 5}

Percentile Plot of LARgest Voting Blocks in ItALian LiSTEd Firms

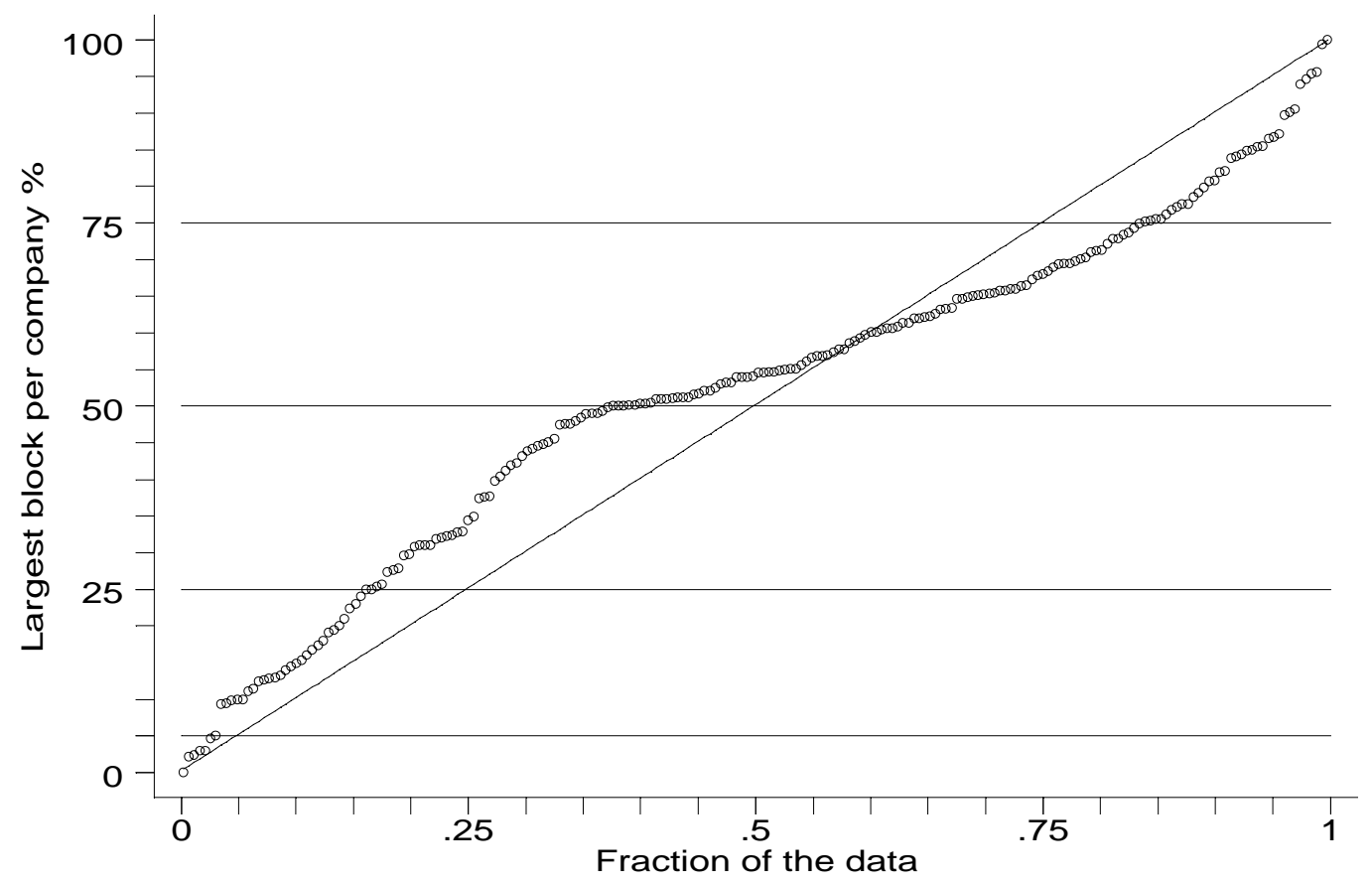

Source : Bianchi, Bianco, Enriques (2000) 


\section{FigURE 6}

\section{Percentile Plot of Largest Voting Block in the Netherlands}

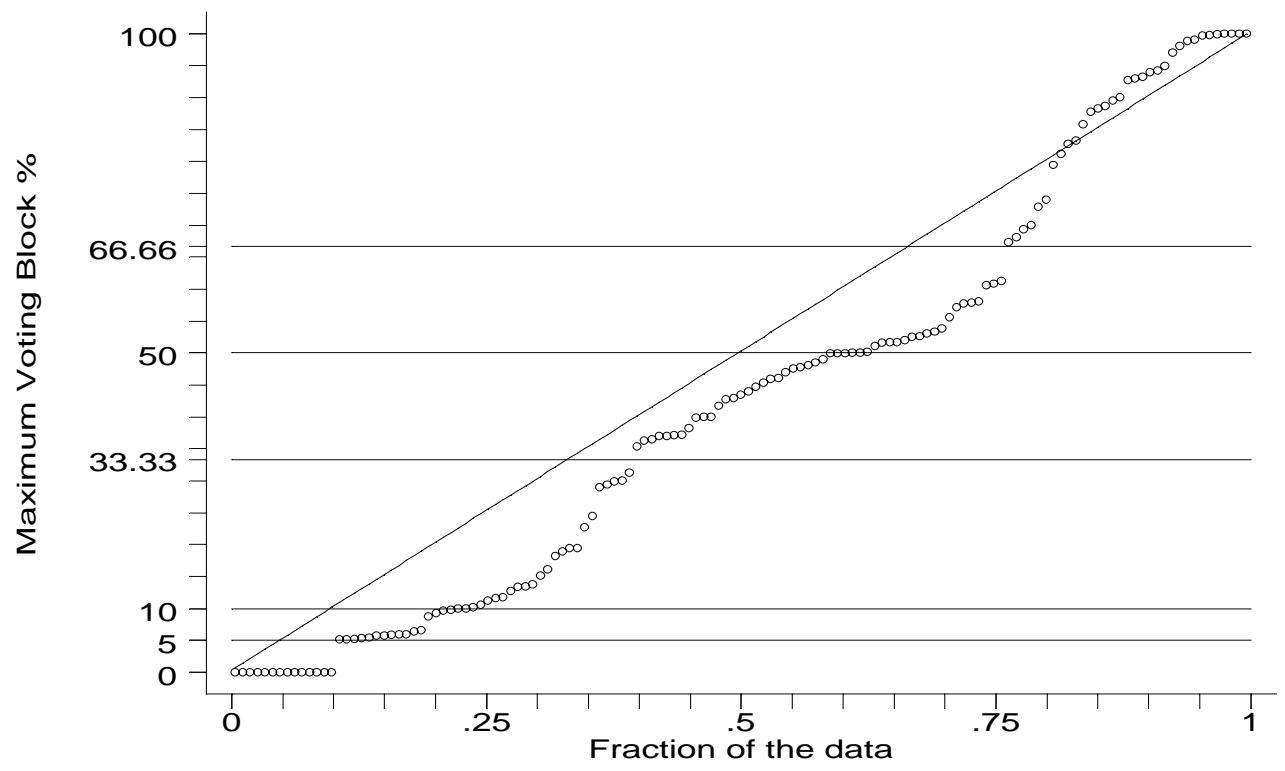

Source : de Jong, Kabir, Marra and Röell (2000)

\section{FIGURE 7}

Percentile Plot of Largest Voting Block in SPain

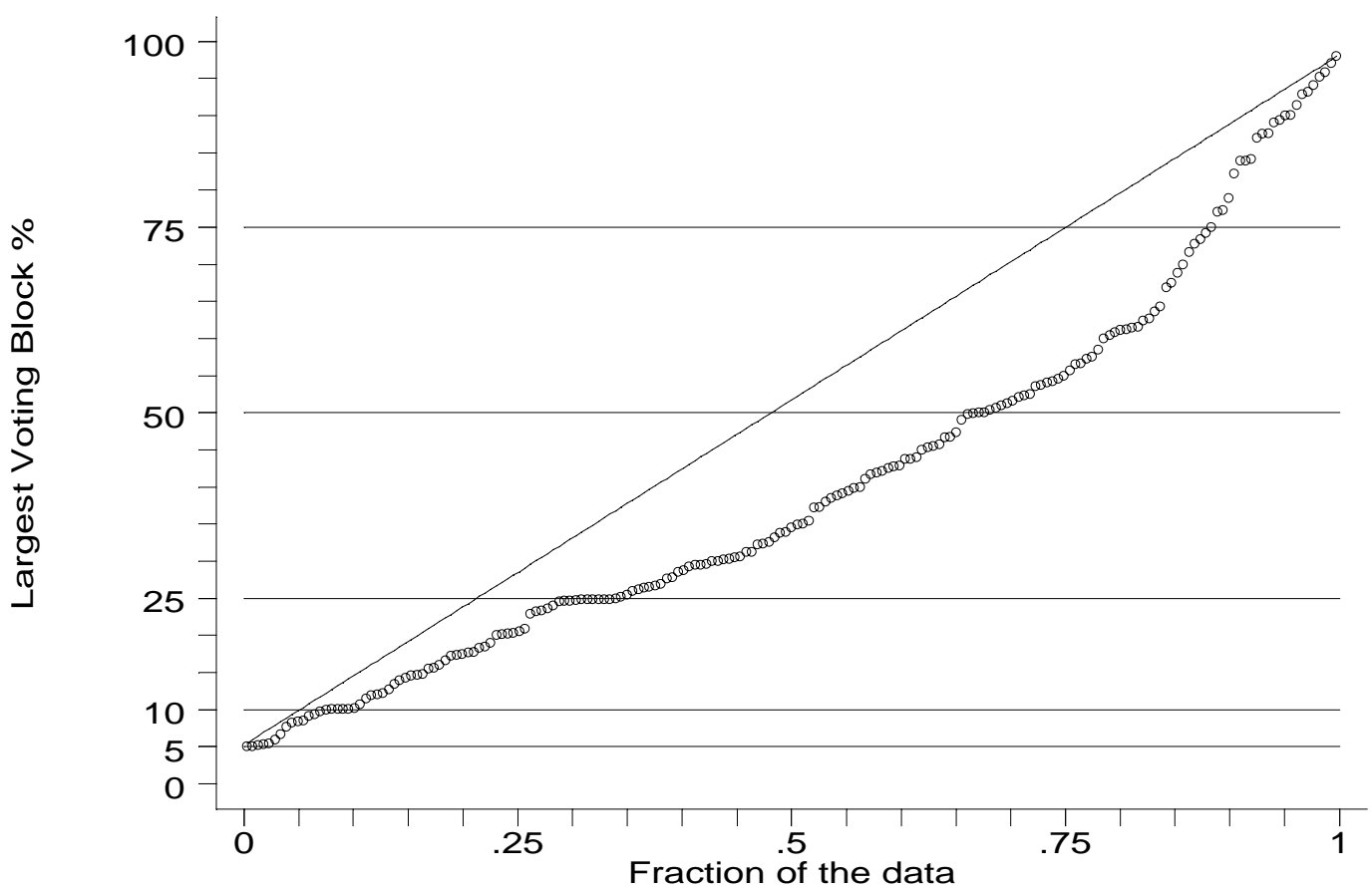

Source : Crespí-Cladera and García-Cestona (2000) 


\section{FigURE 8}

Percentile Plot of Largest Voting Block in Sweden

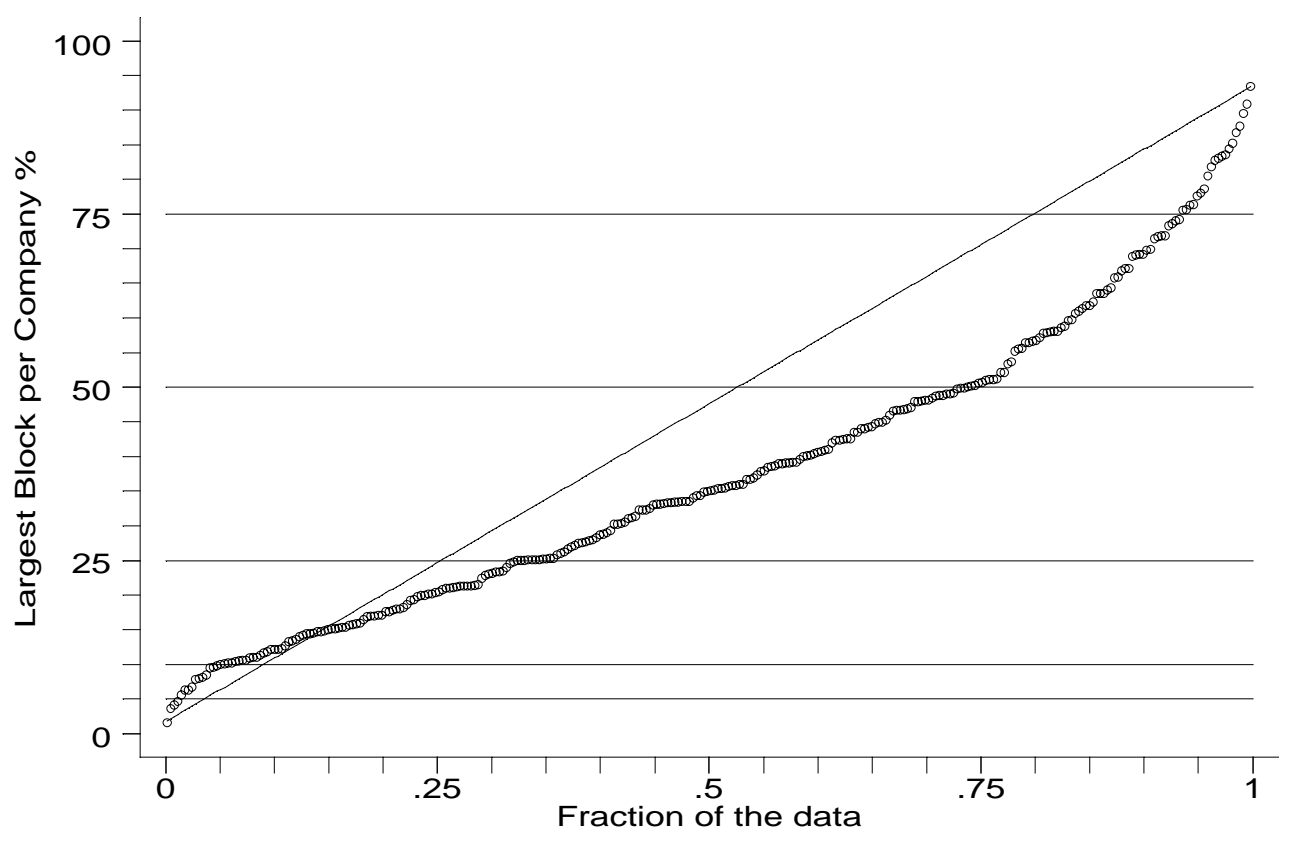

Source : Agnblad, Berglöf, Högfeldt, Svancar (2000)

\section{FIGURE 9}

Percentile Plot of Largest Voting Block in UK Listed Companies

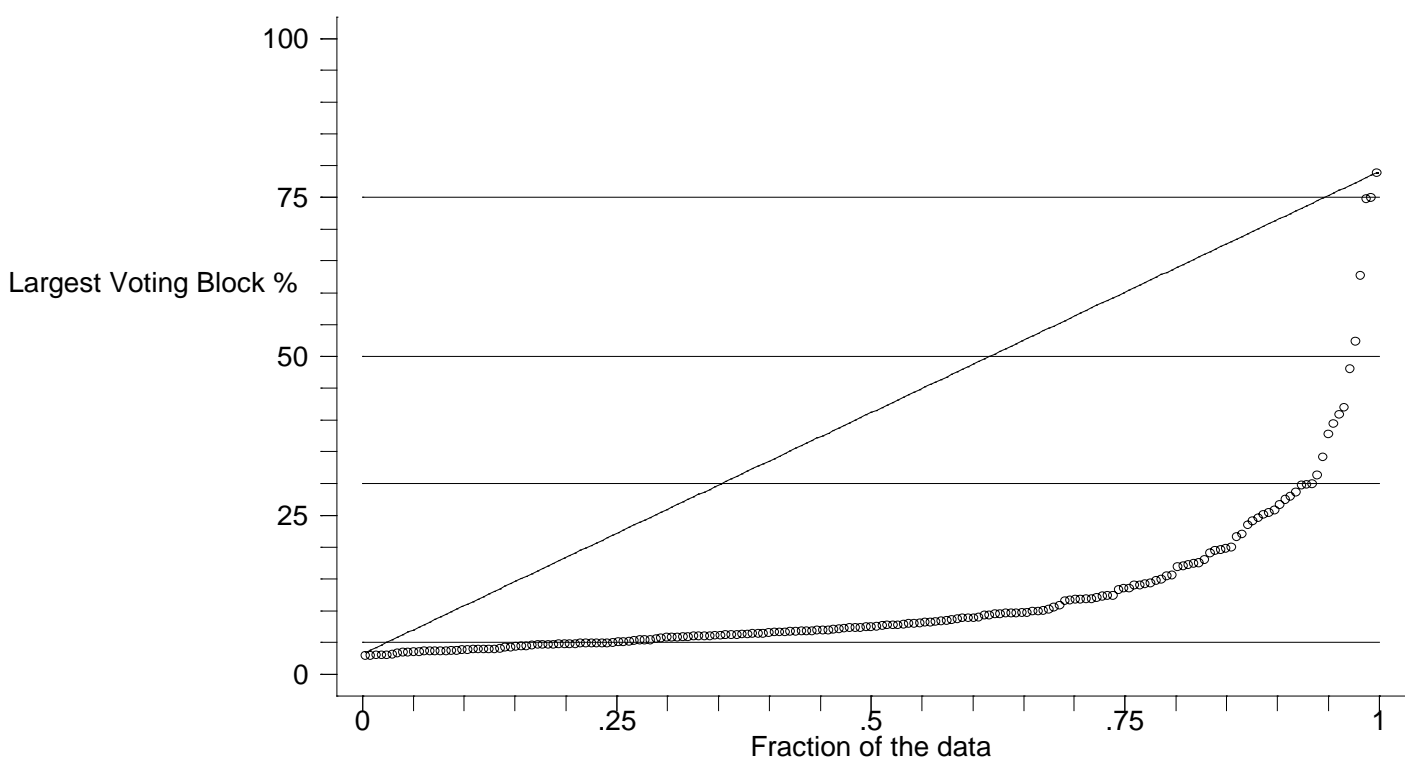

Note : Annual reports for a sample of 250 randomly selected companies.

Source : Goergen and Renneboog (2000) 
FIGURE 10

Percentile Plot of LaRgest Voting Block for U.S. CoMPanies LiSTEd ON THE NYSE

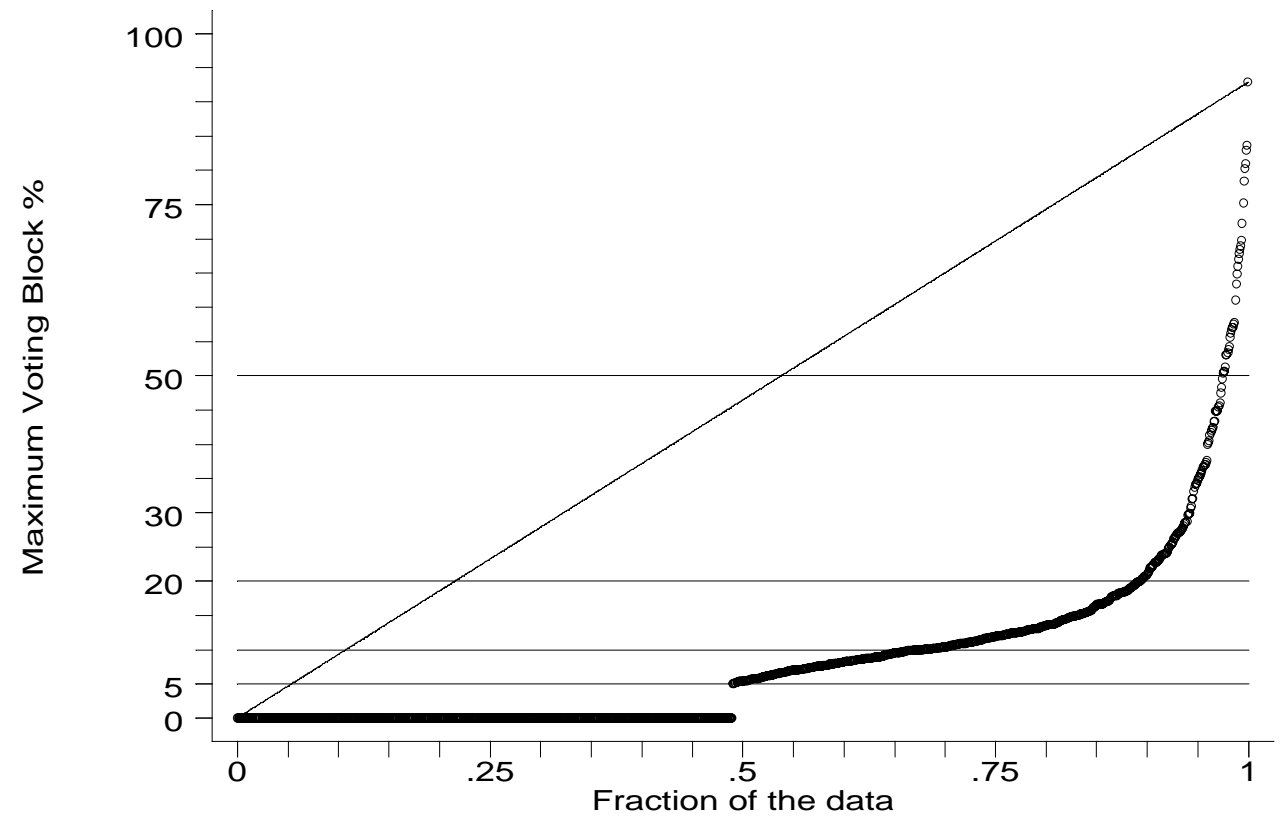

Source : Becht (2000)

FIGURE 11

PerCentile Plot of LARgest Voting Block for U.S. COMPANiES LiSTEd ON NASDAQ

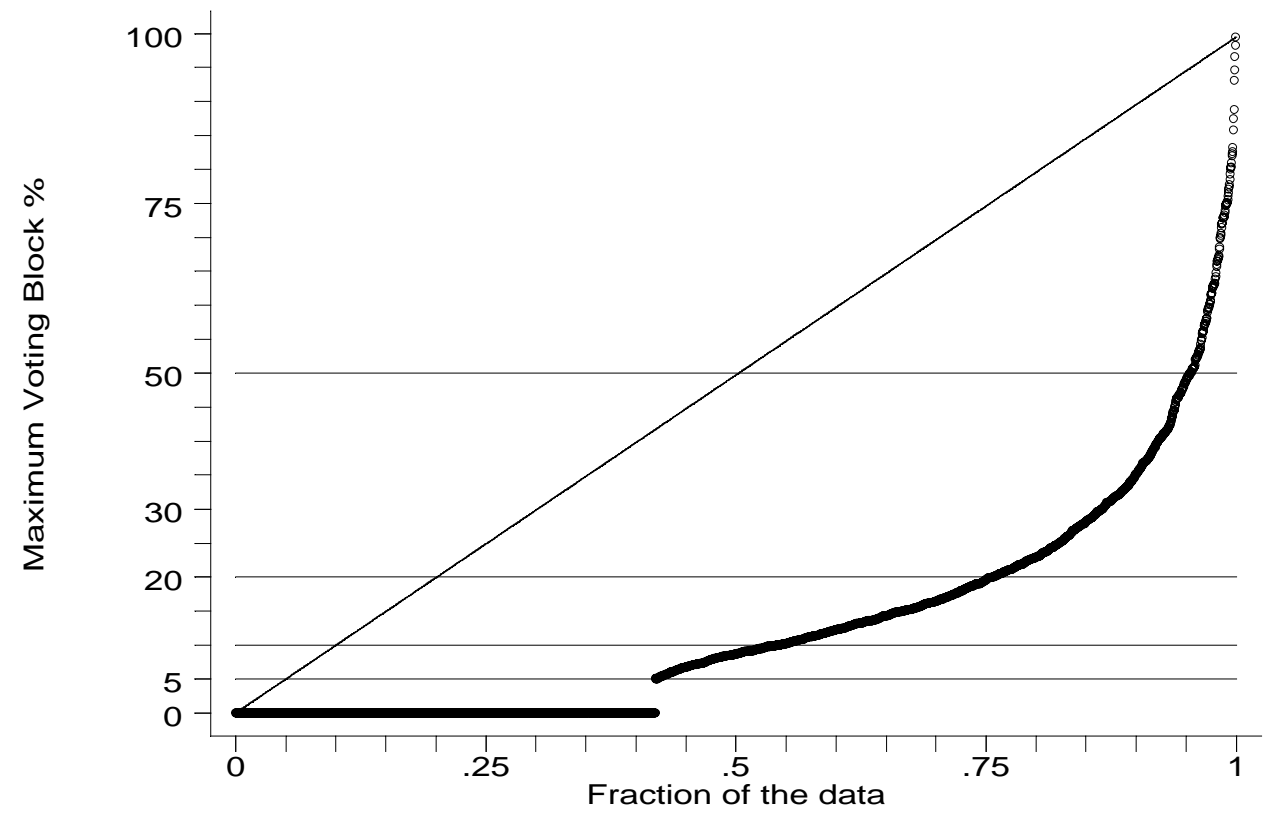

Source : Becht (2000) 
FIGURE 12

\section{Percentage OF Voting Blocks Associated With Different TyPes OF INVESTORS IN THE UK}

Financial institutions, pension funds and life insurance companies are the dominant class of shareholders in the UK. They hold $62 \%$ of the recorded blocks in the UK. Directors hold $24 \%$ of the blocks, companies $8 \%$ and individuals 5\%. For the raw counts, see table 2.

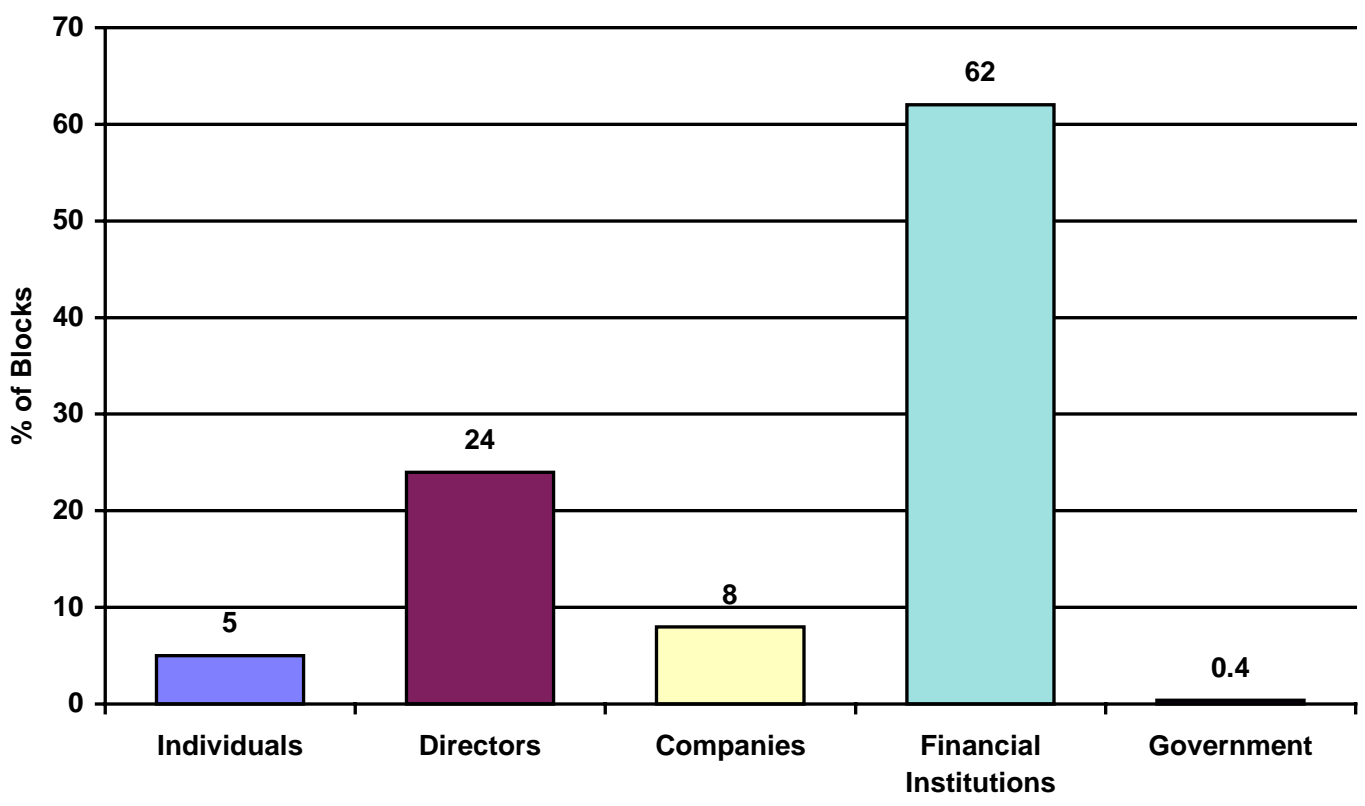


FIGURE 13

\section{PERCENTAGE OF Voting BLOCKS ASSOCIATED WITH DIFFERENT TYPES OF INVESTORS IN GERMANY AND AUSTRIA}

Germany and Austria, families and individuals and other companies dominate the blockholdings. In Germany, individuals and families hold $32 \%$ of blocks, other companies $28 \%$, trusts and holding companies $21 \%$, financial institutions $17 \%$ and government 3\%. In Austria, individuals and families hold $45^{\circ}$ of blocks, companies $36 \%$, financial institutions $11 \%$ and government $9 \%$. \%. For the raw counts, see table 2.

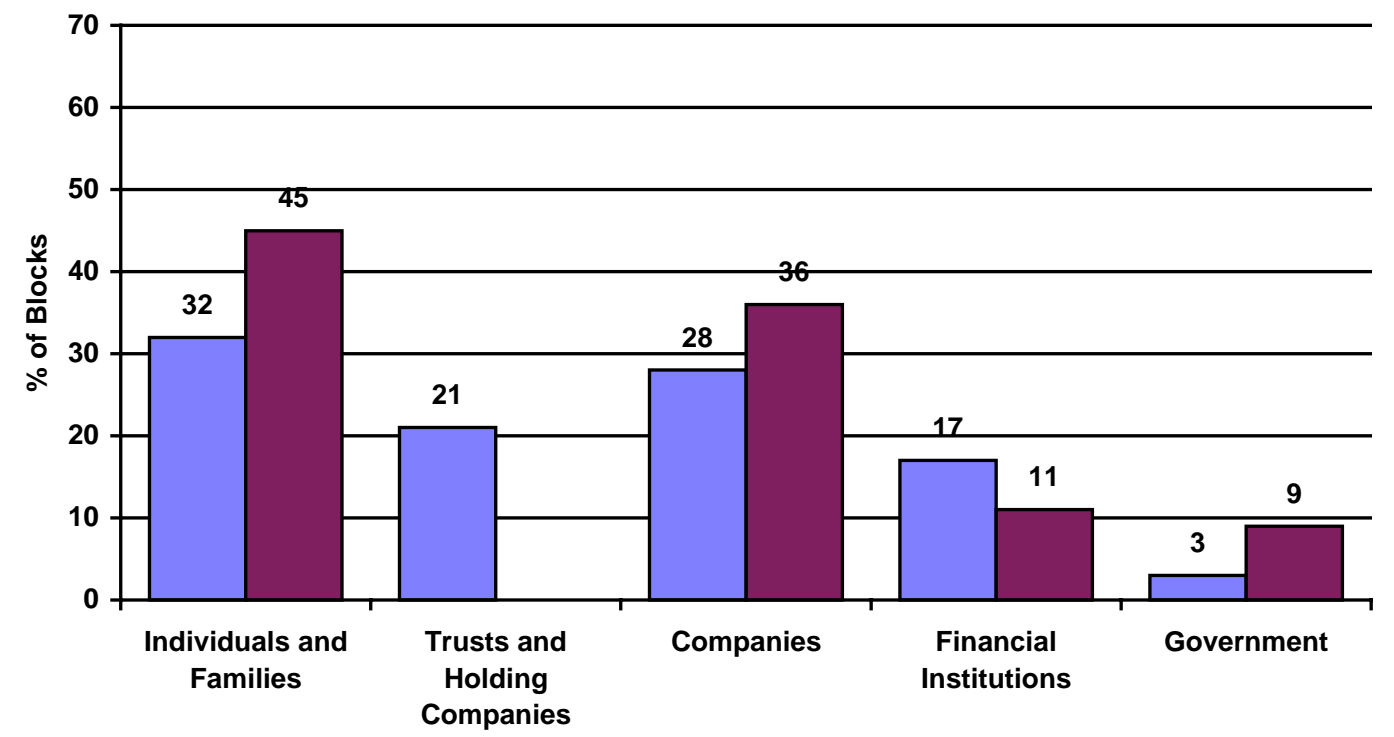

口Germany $\square$ Austria 


\section{FIGURE 14}

\section{MAJORITY CONTROL AND CONCENTRATED OWNERSHIP : SOLVAY S.A.}

Solvay S.A. has three known shareholder groups: the Boel, Solvay and Janssen families (29\%), Solvac S.A. $(25 \%)$ and the company's employees (1\%). Solvac S.A. is a holding company that has been formed to control Solvay S.A. Although Solvac is listed, it has issued registered shares that can only be held by private investors. Solvac's stock is illiquid and on 31 December 1998 it was estimated to trade, compared to the company's intrinsic value, at a discount of $28.6 \%$ (Banque Degroof 1999). Solvac introduces a small degree of pyramiding into this control structure. Through Solvac S.A., the families exert majority control. To protect the company further, for example against family disputes, Solvay has entered an anti-takeover pact with "friends" (Sofina S.A., Deutsche Bank AG, and Génerale de Banque S.A.). The Boel, Solvay and Janssen families control Sofina S.A. (Banque Degroof 1999).

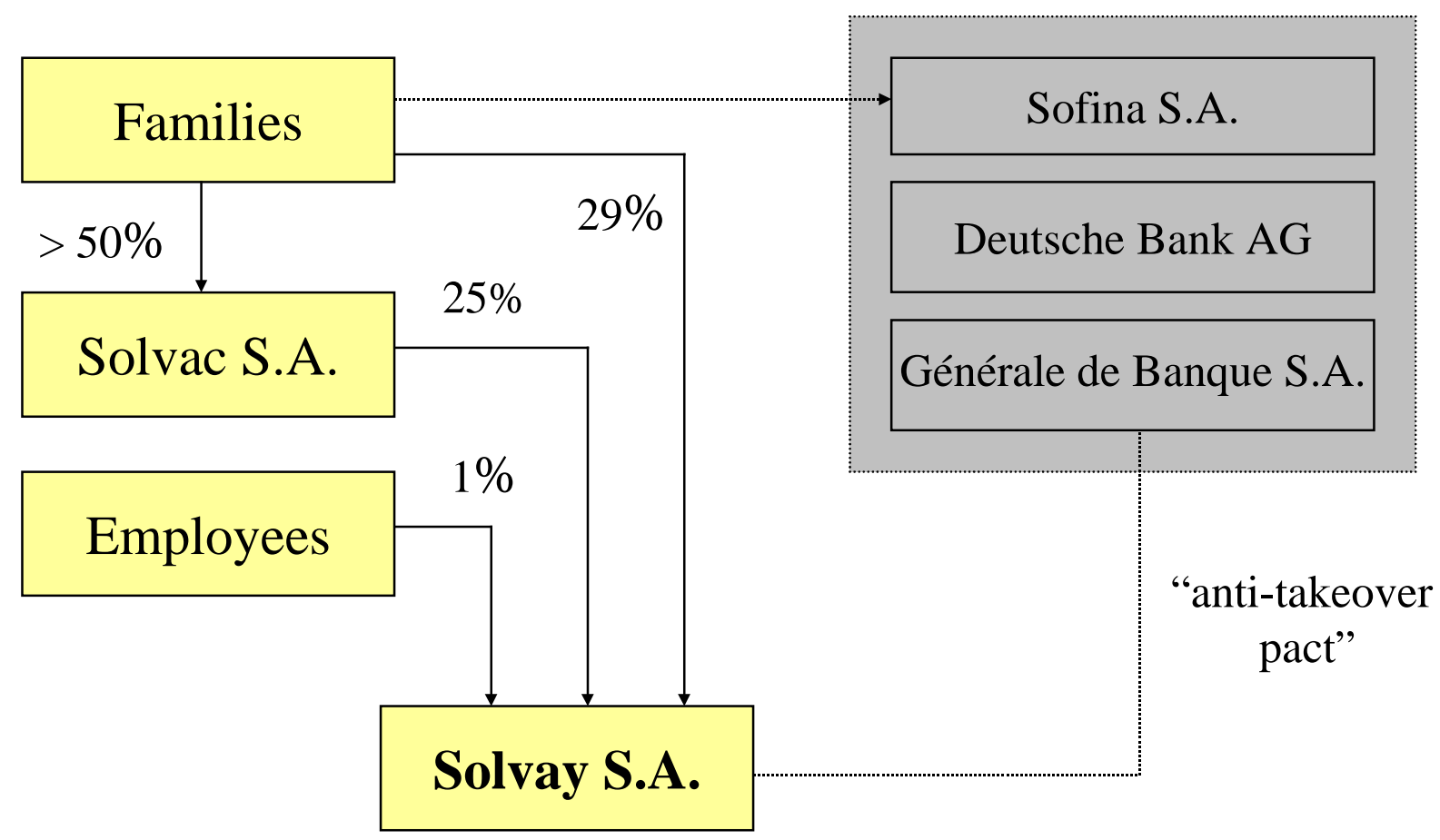




\section{FIGURE 15}

\section{Management Control Through Legal Devices : UniLeVer PlC/NV}

Unilever Plc/NV has a complicated control structure. NV has locked control into Plc, and vice versa. In addition, NV leverages voting power through a trust company and uses preference shares to fend off unsolicited bids for control. Cross-lock in: NV has the sole right to nominate directors for election at Plc, and vice-versa. This is achieved through a cross-holding structure involving two holding companies, N.V. Elma and United Holdings Limited that hold $50 \%$ of special shares and deferred shares in NV and Plc. Since N.V. Elma is a subsidiary of NV and United Holdings Ltd of Plc, Elma cannot vote its special shares of NV and United Holdings cannot vote its deferred shares in Plc (Unilever Form 20-F 1998, page 33). Hence, the other shareholders of NV and Plc can refuse to elect the directors Plc and NV nominate, but they cannot nominate other directors for election. In addition, "each of Unilever's ten directors is a full-time executive and is a director of both NV and Plc" (Unilever Annual Review 1998, English Version in Guilders). Voting power leverage: NV has issued 3 classes of shares; special shares $(\ddagger)$, ordinary shares $(*)$, and three types of cumulative preference shares $(7 \%, 6 \%, 4 \% ; \dagger)$, representing $0.3 \%, 70.5 \%$ and $29.2 \%$ of par-value respectively. Nedamtrust holds $66.6 \%$ of the ordinary shares and $3.8 \%$ of the cumulative preference shares. For its $66.6 \%$ stake in the ordinary shares it has issued non-voting certificates that are traded on the stock market. Nedamtrust itself is owned and controlled by ANT. Veto power of preference shareholders: ING and Aegon hold approx. 91\% of the cumulative preference shares. In the unlikely that a bidder would acquire the ordinary shares of Plc or NV, the bidder would be unable to break up the "equalisation and other agreements" that bind Plc and NV without the consent of $2 / 3$ of the preference shareholders.

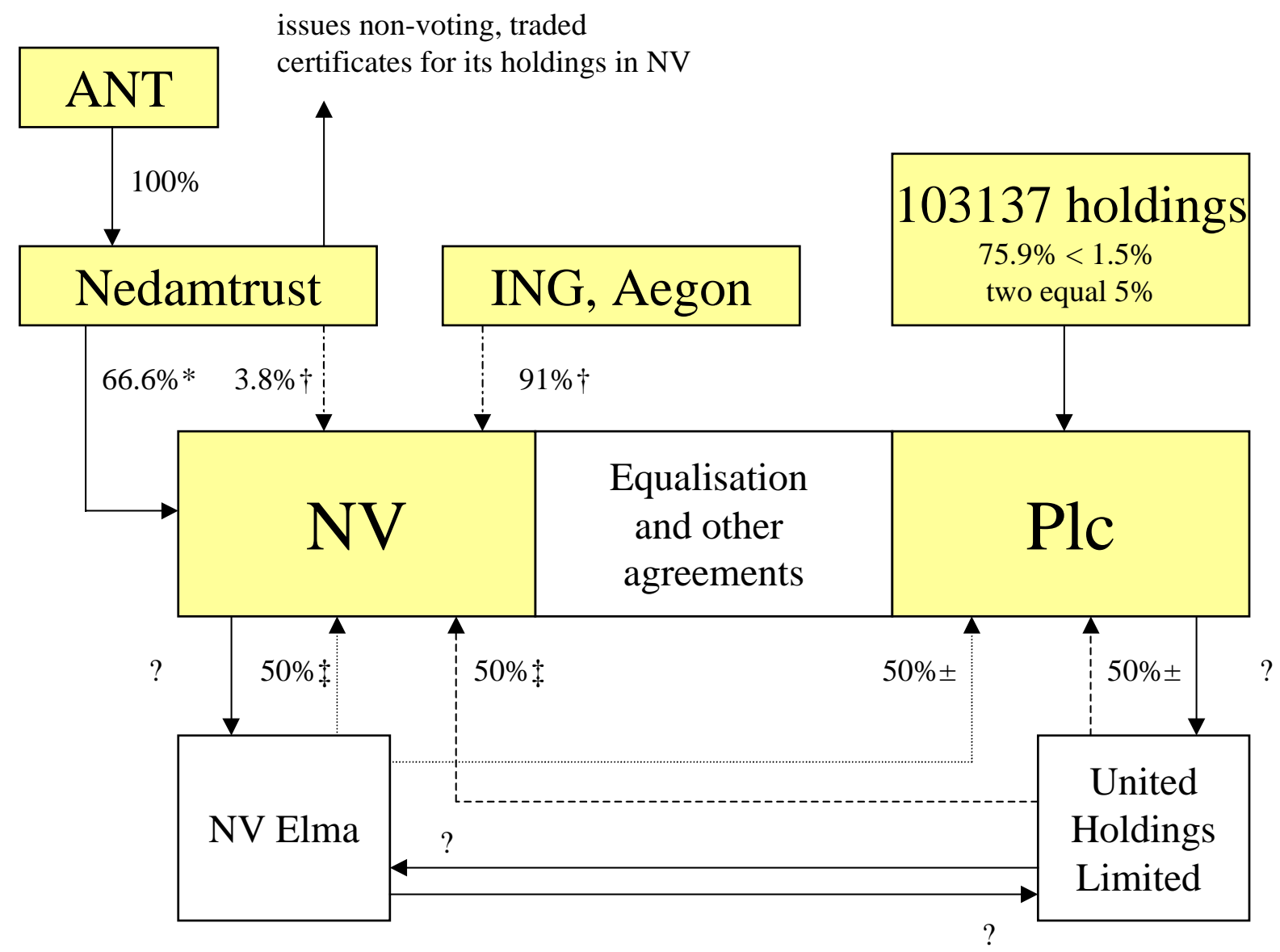




\section{TABLE 1}

\section{SIZE OF ULTIMATE VoTING BLOCKS BY RANK}

The table reports the size of the largest, $2^{\text {nd }}$ largest and $3^{\text {rd }}$ largest median voting block for non-financial companies listed on an official market. For France only the main stock price index (CAC40 is covered).

\begin{tabular}{|c|c|c|c|c|}
\hline 1 & 2 & 3 & 4 & 5 \\
\hline Country & $\begin{array}{l}\text { No. of } \\
\text { Comp. }\end{array}$ & $\begin{array}{c}\text { Largest Voting } \\
\text { Block } \\
\text { Median } \\
\end{array}$ & $\begin{array}{c}2^{\text {nd }} \text { Largest Voting } \\
\text { Block } \\
\text { Median }\end{array}$ & $\begin{array}{c}3^{\text {rd }} \text { Largest Voting } \\
\text { Block } \\
\text { Median }\end{array}$ \\
\hline Austria [1] & 50 & 52.0 & 2.5 & $0.0 *$ \\
\hline Belgium [2] & 140 & 56.0 & 6.3 & 4.7 \\
\hline Germany [3] & 372 & 57.0 & $0 *$ & $0 *$ \\
\hline Spain [4] & 193 & 34.5 & 8.9 & 1.8 \\
\hline France [5] & CAC 40 & 20.0 & 5.9 & 3.4 \\
\hline Italy [6] & 214 & 54.5 & 5.0 & 2.7 \\
\hline Netherlands [7] & 137 & 43.5 & 7.7 & $0 *$ \\
\hline Sweden [8] & 304 & 34.9 & 8.7 & 4.8 \\
\hline U.K. [9] & 207 & 9.9 & 6.6 & 5.2 \\
\hline \multicolumn{5}{|l|}{$\begin{array}{r}\text { United States } \\
{[10]}\end{array}$} \\
\hline NYSE & 1309 & 5.4 & $0 *$ & $0 *$ \\
\hline NASDAQ & 2831 & 8.6 & $0 *$ & $0 *$ \\
\hline
\end{tabular}

Notes: * - there is no $5 \%+$ voting block.

Sources: [1] Gugler, Kalss, Stomper and Zechner, Figure 1, data for 1996. [2] computed by Becht, data for 1995 [3] Becht and Böhmer, Figure 2, data for 1996; [4] Crespí-Cladera and García-Cestona; [5] Bloch and Kremp, , [6] Bianchi, Bianco, Enriques, Table 6, data for 1996; [7] de Jong, Kabir, Marra and Röell, Table 4, data for 1996; [8] Agnblad, Berglöf, Högfeldt, Svancar, Table III A, data for 1998, [9] Goergen and Renneboog, data for 1992; excludes blocks held by directors [10] Becht, includes blocks held by directors and officers; data for 1996. 
TABle 2. VOTING BLOCKS BY BLOCKHOLDER TYPE

\begin{tabular}{|c|c|c|c|c|c|c|c|c|c|c|c|c|c|c|c|}
\hline \multirow[b]{2}{*}{ Range } & \multicolumn{5}{|c|}{ Austria [1] } & \multicolumn{5}{|c|}{ Germany [2] } & \multicolumn{5}{|c|}{ Spain [3] } \\
\hline & No. & Min & Mea & Med & Max & No. & Min & Mea & Med & Max & No. & Min & Mea & Med & $\operatorname{Max}$ \\
\hline Government & 9 & 24.0 & 53.1 & 51.0 & 81.6 & 18 & 8.2 & 45.3 & 40.7 & 99.0 & 37 & 5.7 & 46.8 & 49.0 & 95.2 \\
\hline Banks & \multirow{2}{*}{11} & \multirow{2}{*}{6.4} & \multirow{2}{*}{42.0} & \multirow{2}{*}{41.9} & \multirow{2}{*}{100} & 77 & 5.1 & 23.8 & 15.0 & 99.0 & 48 & 5.0 & 21.2 & 13.6 & 91.5 \\
\hline Insurance & & & & & & 34 & 5.0 & 11.9 & 20.1 & 96.7 & 56 & 5.0 & 20.8 & 14.6 & 91.5 \\
\hline Families/Individ. & 45 & 5.0 & 26.0 & 12.3 & 100 & 205 & 5.0 & 26.9 & 18.2 & 100 & 163 & 5.0 & 16.0 & 9.5 & 87.5 \\
\hline Domestic Firms & 10 & 6.6 & 39.4 & 51.5 & 64.3 & \multirow{2}{*}{180} & \multirow{2}{*}{5.0} & \multirow{2}{*}{61.6} & \multirow{2}{*}{70.6} & \multirow{2}{*}{100} & 203 & 5.0 & 24.1 & 16.7 & 98.0 \\
\hline Foreign Firms & 26 & 5.7 & 31.6 & 18.7 & 87.0 & & & & & & 125 & 5.0 & 20.7 & 9.1 & 97.2 \\
\hline Assoc./pools & & & & & & 21 & 5.9 & 45.2 & 49.1 & 100 & & & & & \\
\hline Holding & & & & & & 53 & 6.9 & 52.9 & 50.3 & 100 & & & & & \\
\hline Investment Firm & & & & & & 36 & 5.5 & 25.1 & 40.0 & 99.0 & & & & & \\
\hline Bank rel.inv.firm & & & & & & 5 & 10.2 & 18.1 & 11.0 & 41.4 & & & & & \\
\hline Foundation & & & & & & 16 & 8.0 & 50.1 & 51.6 & 98.1 & & & & & \\
\hline Other & & & & & & 3 & 13.0 & 18.9 & 20.2 & 23.6 & & & & & \\
\hline \multirow[t]{2}{*}{ All Blocks } & 101 & 5.0 & 33.1 & 22.7 & 100 & 648 & & & & & 632 & 5.0 & 20.7 & 12.3 & 98.0 \\
\hline & \multicolumn{5}{|c|}{ Italy [4] } & \multicolumn{5}{|c|}{ The Netherlands [5] } & \multicolumn{5}{|c|}{ United Kingdom [6] } \\
\hline Range & No. & Min & Mea & Med & Max & No. & Min & Mea & Med & Max & No. & Min & Mea & Med & Max \\
\hline Government & 34 & 0 & 6.8 & 0 & 97.4 & & & & & & 6 & & 6.7 & & \\
\hline Banks & 156 & 0 & 9.5 & 0 & 95.6 & 48 & 0.0 & 4.4 & 0.0 & 39.8 & 71 & & 5.1 & & \\
\hline Insurance & 13 & 0 & 1.1 & 0 & 93.9 & 34 & 0.0 & 8.3 & 0.0 & 93.0 & 226 & & 4.0 & & \\
\hline Families/Individ. & 234 & 0 & 20.1 & 0 & 95.4 & 36 & 0.0 & 8.9 & 0.0 & 97.1 & 61 & & 5.2 & & \\
\hline Domestic Firms & 160 & 0 & 20.3 & 2.0 & 100 & 22 & 0 & 14 & 00 & 270 & 102 & & 106 & & \\
\hline Foreign Firms & 116 & 0 & 9.1 & 0 & 99.9 & 22 & 0.0 & 1.4 & 0.0 & 21.0 & & & & & \\
\hline Invest./Pen. Fund & & & & & & 6 & 0.0 & 0.4 & 0.0 & 19.0 & 474 & & 7.0 & & \\
\hline & 57 & 0 & 0.8 & 0 & 8.9 & & & & & & & & & & \\
\hline Exec. Directors & & & & & & & & & & & 117 & & 4.5 & & \\
\hline Non-Exec. Direc. & & & & & & & & & & & 184 & & 5.0 & & \\
\hline Real Estate & & & & & & & & & & & 1 & & 0.1 & & \\
\hline Other Financ. Inst. & 18 & 0 & 1.1 & 0 & 66.9 & 61 & 0.0 & 11.1 & 0.0 & 85.6 & & & & & \\
\hline State & & & & & & 4 & 0.0 & 1.1 & 0.0 & 50.0 & & & & & \\
\hline Admin. Office & & & & & & 54 & 0.0 & 26.9 & 0.0 & 100 & & & & & \\
\hline Total & 788 & 0 & 68.4 & 71.5 & 100 & & & & & & 1242 & & & & \\
\hline
\end{tabular}

Sources : [1] Gugler, Kalss, Stomper and Zechner, Table 7, data for 1996; [2] Becht and Böhmer, Table 5, data for 1996; [3] Crespí-Cladera and García-Cestona, , data for 19xx; [4] Bianchi, Bianco, Enriques, data for 1996; [5] de Jong, Kabir, Marra and Röell, Table 6, data for 1996; [6] Goergen and Renneboog, data for 1992. 


\section{Endnotes}

${ }^{1}$ Av. F. D. Roosevelt 50, Université Libre de Bruxelles, CP 114, 1050 Brussels, Belgium, Tel./Fax.: +32-(2)-650.4466, Fax.: +32-(2)-650.4475, e-mail : mbecht@ulb.ac.be,

http://homepages.ulb.ac.be/ mbecht

${ }^{2}$ Radcliffe Infirmary, Woodstock Road, Oxford OX2 6HE, UK, Tel: +44 1865 228476, Fax: +44 1865 228566, Email: colin.mayer@sbs.ox.ac.uk.

${ }^{3}$ It is unclear whether the La Porta (et al) study refers to the largest 20 companies in each of their countries or the largest 20 companies in Worldscope, which is their main data source. Since Worldscope coverage is far from comprehensive, the 20 companies do not necessarily correspond with the largest 20 in any one country.

${ }^{4}$ In the political theory of Roe (1991) U.S. managers influence regulation to obtain or protect rents.

${ }^{5}$ Financial Times, 27 April 2000, French groups curb voter rights, By Samer Iskandar and Simon Targett. 